Accepted Manuscript: This is the version of the article that was accepted for publication in the British Journal for the History of Science, Cambridge University Press, prior to editorial input.

The published version is:

Olohan, Maeve (2013) ‘Gate-Keeping and Localising in Scientific Translation Publishing: The Case of Richard Taylor and Scientific Memoirs', British Journal for the History of Science, FirstView articles, DOI: http://dx.doi.org/10.1017/S0007087413000368, Published online: 11 July 2013

Copyright (c) British Society for the History of Science 2013 


\title{
Gate-Keeping and Localising in Scientific Translation Publishing: The Case of Richard Taylor and Scientific Memoirs
}

\author{
Growing interest in studying translation through a sociological lens and the relative lack of \\ attention by translation scholars to the production of scientific translations provide impetus \\ and rationale for this case study. Richard Taylor's editorial work for the Scientific Memoirs \\ periodical is examined, with a particular focus on his conception of the utility of translation in \\ the service of scientific advancement in Britain. The roles of gate-keeper and localiser of \\ scientific material are attributed to Taylor, roles which he exercised through promotion of \\ scientific translation, selection of texts to publish and editorial interventions in translations. \\ The historical case study sheds light on activities of editing, translating and publishing \\ science in mid-19th century Britain but is also illustrative of research areas where the \\ interests of translation scholars and historians of science may converge. By centring \\ attention on Taylor's editorial role, some of the material and social contingencies of this \\ publishing activity are highlighted, enabling us to gain a deeper appreciation of scientific \\ translation as socio-historical practice.
}

Chronological accounts of the development of translation studies usually start from early statements by translators, from Cicero and St. Jerome to Luther, reflecting debates on literal vs. free translation and a grappling with notions of fidelity, often in the context of translating sacred texts. ${ }^{1}$ Similar debates are documented in non-Western traditions. ${ }^{2}$ The principles and approaches advocated by scholars such as Dryden, Dolet, Tytler and Schleiermacher from the $17^{\text {th }}$ century onwards are seen as the first attempts to produce theories of translation. However, the academic discipline of translation studies, which seeks to provide more systematic investigations and accounts of translation, did not emerge until the second half of the $20^{\text {th }}$ century. One of the preoccupations of translation studies in the 1960 s was the notion of equivalence and the nature of relationships between source and target 
texts, influenced by Chomskyan linguistics and contrastive stylistics. The 1970 s saw a shift towards functional accounts of translation, which viewed translation as purposeful action and the source text as an offer of information which translators, as intercultural experts, adapt in order to fulfil an intended function in the target culture. Also from the 1970s, polysystem theory brought an approach which studied the position of translations as part of target literary and historical systems. These and other descriptive approaches continue to encourage the study of translations as they are, their causes and their effects, rather than idealised notions of what translations should be. Many other methodological developments and thematic interests have run alongside or emerged from these broad trends (postcolonial translation studies, corpus-based translation studies, feminist theories of translation, cognitive and psycholinguistic approaches, among others). In general terms, translation scholarship over those decades may be characterised as moving away from static and prescriptive models of decontextualised translation to more dynamic accounts informed by description and analysis of translated texts within their target systems.

While necessarily brief, this outline may serve to situate the most recent theoretical trend in translation studies, which can be described as sociological. While some of the approaches mentioned above also view translation as social practice, the 'sociology of translation' focuses even more explicitly on translators and translator agency, on the mechanisms by which translation influences and is influenced by social change, on the dynamism of interactions and power struggles in translation and related fields. ${ }^{3}$ This work is informed by social theorists, notably Bourdieu and, to a lesser extent, Luhmann, Latour and Giddens. ${ }^{4}$ Since translators act on and through texts, textual and comparative analyses remain relevant. However, many studies of translation are no longer predominantly linguistic or philological in their orientation; texts are increasingly contextualised through exploration of the situations of their production and reception, including the working environment and conditions of translators, the role and status of translators in society, the impact of translations and the interactions between translators and authors, editors and others involved in the 
translation production process. Nonetheless, the translation of science has attracted less attention from translation scholars than literary or Bible translation, both generally and in recent sociological accounts. ${ }^{5}$ Scientific translation remains under-theorised and under-researched by translation scholars, with the exception of a small number of contributions to the history of translation, and there is considerable scope to enhance our understanding of translation as social practice by considering it also in scientific contexts. ${ }^{6}$

This paper seeks to make a contribution to this scholarship which may be of interest to both translation scholars and historians of science. Its focus is a scientific periodical, Scientific Memoirs, published in London between 1837 and 1852, and its editor, Richard Taylor. Taylor founded this periodical for the purpose of publishing translations and he was both its editor and publisher, and also translated some material for it. The published periodical volumes and related archival material permit exploration of this episode of scientific translation publishing in Britain from several different angles and employing a variety of methods. For example, comparative analysis of source and target texts and their contexts of production may enable us to identify translation problems and strategies. Through archival research we may uncover details of the circumstances and motives of the men of science who aided Taylor in various ways, and the women who translated for him. ${ }^{7}$ Examination of reviews and citations may facilitate a study of the reception of the translations and the trajectory of the scientific ideas they conveyed. Such avenues of inquiry seek to elucidate the causes and effects of the translation of science in 19th-century Britain and enhance our understanding of the role of translation in the development and circulation of scientific ideas in $19^{\text {th }}$-century Europe, thus potentially addressing issues of pertinence for both translation studies and history of science.

From the diverse range of approaches available, I have chosen to concentrate here on Richard Taylor's editorial role, for perhaps obvious reasons. Taylor was the lynchpin of this translating and publishing endeavour; he established the periodical and ensured that it continued beyond Volume 1. I first examine Taylor's conception of the utility of translation and seek to 
establish the extent to which his perspective resonated among individuals and institutions around him. I then discuss Taylor's editorial activities in terms of gate-keeping and localising functions. The gate-keeping function prompts consideration of the factors influencing decisions about what was and was not translated. The localising function is studied by analysing Taylor's editorial interventions, through which he sought to contextualise scientific material for his readers by drawing on the body of scholarship with which they were already familiar. This Taylor-centred narrative brings into relief some of the social and material aspects of the translation and editing activity, but also invites one possible explanation for the fate of Scientific Memoirs, drawing on Philpotts' Bourdieu-inspired characterisation of modes of journal editorship. ${ }^{8}$

\section{Translation, scientific progress and Taylor's Scientific Memoirs}

The Taylor \& Francis publishing house assumes a central role in the history of science in Britain, not least because it published and owned key periodicals in science, including the Annals of Science, the Annals of Natural History and the Philosophical Magazine. The eponymous Taylor \& Francis were Richard Taylor and his son William Francis, both highly respected by the men of science who were their contemporaries. ${ }^{9}$ In the 1830 s Taylor conceived of a new periodical which would be a vehicle for the publication of translations into English of scientific papers and memoirs, Scientific Memoirs, Selected from the Transactions of Foreign Academies of Science and Learned Societies, and from Foreign Journals (henceforth Scientific Memoirs). ${ }^{10}$ It was advertised to be continued quarterly; Volumes 1-4 did appear in four parts but these were not published at quarterly intervals, and Volume 5 had five parts. The five volumes under Taylor's editorship were completed in 1837, 1841, 1843, 1846 and 1852, making an average of 680 pages per volume. ${ }^{11}$ Taylor's health declined in 1852 and he passed the management of Scientific Memoirs into the hands of John Tyndall and William Francis, who were to edit a series on natural philosophy, and Arthur Henfrey and Thomas Henry Huxley, responsible for a second series on natural history. Both new series ceased publication after 
only one volume, in 1853. This paper focuses on the five volumes which appeared under Taylor's ownership and editorship.

Taylor's rationale for setting up Scientific Memoirs can be discerned from his prefaces to various volumes of the journals and advertisements and notices for it. In the preface to Volume 1 he asserted that this publication was 'much needed for the progress and advancement of science in this country' since those who were uninformed about the scientific activities of their continental neighbours would be at a great disadvantage. ${ }^{12}$ He exemplified the problem by quoting from Lenz in Scientific Memoirs Volume 1 who argued that Ohm's work on the galvanic battery, published in German, did not become known in France and England until much later. ${ }^{13}$ This point was taken up in an announcement of the launch of Scientific Memoirs which appeared in the Mechanics' Magazine; here it was noted that, had Ohm's and Fechner's work been known in England, Dr [William] Ritchie would have been spared 'a world of trouble in experimenting, as well as in propounding a theory [...] demonstrated to be untenable'. ${ }^{14}$ This view of the publication as being necessary for 'furthering the progress of scientific pursuits in this country by giving readier access to the labours of foreign philosophers' is reiterated by Taylor in advertisements and notices for parts of the first volume. ${ }^{15}$

At first glance, Taylor's stance with regard to disparities between the achievements of British men of science and those of their continental counterparts might appear to have been in accord with Babbage. Babbage had bemoaned the decline of science in England in the preceding years, particularly linked to shortcomings he perceived on the part of the government, the state and the Royal Society in funding, rewarding and otherwise encouraging scientific endeavour. ${ }^{16}$ However, Taylor's argument was somewhat different. He asserted that the extent of scientific activities in Britain left little space in periodicals like the Philosophical Magazine for foreign research to be reported. ${ }^{17}$ This particular reading enabled the editors of the Mechanics ${ }^{\prime}$ Magazine, who disagreed with Babbage and his supporters, ${ }^{18}$ to use Taylor's statement as an argument against the 'incessant din of the "decline of Science in England", which it has pleased certain of our peevish philosophers 
to raise' ${ }^{19}$ They elaborated this point by referring to Lenz's aforementioned article; Lenz, they argued, provided 'a tough morsel for the Declinarians' because he had listed those men of science who had made contributions to research on electricity, and eight of the fourteen men named were British. ${ }^{20}$ Despite this evidence of the healthy state of British science, the Mechanics' Magazine was strongly in favour of Taylor's initiative, admitting that a knowledge of European science was lacking among some British men of science and entreating the scientific word to support Taylor, as editor, printer and proprietor - 'tria juncta in uno' - in this undertaking. ${ }^{21}$ Existing journals published some English-language abstracts of foreign works and occasional translations of complete works but on an ad-hoc basis. This coverage could have been expanded but Taylor ruled it out as commercially unviable. ${ }^{22}$ He chose instead to 'experiment' by publishing a periodical dedicated to translations. ${ }^{23}$

Evidence given by Taylor before a Parliamentary Select Committee on Postage in 1838 provides insights into his views on the communication and dissemination of science which informed his establishment of Scientific Memoirs and his promotion of the translation of science. Taylor perceived a need for more rapid communication of discoveries than was experienced at that time. ${ }^{24}$ There were, he argued, 'plenty of things brought forward in this country as late discoveries, that have been perfectly well known in Germany for 10 or 12 years past, which have appeared in journals there not known here; it would be a very great advantage to men of science to have a more speedy diffusion of discoveries in this country'. ${ }^{25}$ Journals played an important role in this dissemination but very few foreign journals were taken in England, he noted, due to the expenses and difficulties of receiving them. ${ }^{26}$ Journal editors also had an important role to play to achieve dissemination, in Taylor's view, by exchanging journals across national borders, but this activity was impeded by prohibitive postage costs or the precariousness of transmission by hand from abroad via the Foreign Office staff or Members of Parliament. ${ }^{27}$ Taylor reported that he exchanged journals with Poggendorff, Wiegmann and Müller in Berlin, with the publishers of Comptes Rendus in Paris, and with the editors of the Bibliothèque Universelle in Geneva, as well as with Silliman in America. This 
international exchange of journals was not merely commercially advantageous, in Taylor's eyes, but enabled discoveries to be made known quickly around the world. ${ }^{28}$ Scientific Memoirs was part of this dissemination strategy, since it allowed some of the content of those foreign journals to be communicated. Taylor also gave an example of the consequence of a breakdown in this international exchange; for the last three months of the previous year no English scientific journals had been received by the French Institute or at Geneva, which meant that, according to Taylor, 'of course, any discoveries made in England remained unknown abroad' ${ }^{29}$

Thus, Taylor's conception of scientific progress was strongly dependent on publishing, dissemination and international exchange. Speed of exchange was crucial and affordability of exchange was also important. Scientific Memoirs was envisaged as helping to meet those requirements. However, achieving scientific progress in this way meant overcoming commercial constraints. The purpose of the Select Committee had been to examine the issue of postage costs in advance of the introduction of the penny post in 1840, and Taylor's evidence centred on the financial difficulties experienced by scientific publishers and scientific journals, principally due to high postage costs. He acknowledged the advantage he held as editor, printer and publisher (of the Philosophical Magazine, but this also held for Scientific Memoirs). ${ }^{30}$ However, Taylor also made it clear that the first four parts of Scientific Memoirs had not sold sufficiently well to cover costs. Indeed, he had already announced elsewhere in November 1837 that he had suspended the work 'to give an opportunity for men of science to come forward in its support' ${ }^{31}$ Despite having received numerous 'expressions of strong interest', Taylor stated in the preface to Volume 1 of Scientific Memoirs that he had not yet sold 250 copies so had not covered the cost of publication and he appealed for purchasers of the current volume and subscribers for future ones. ${ }^{32}$

The view of Scientific Memoirs which can be formed through the publicity materials prepared by Taylor and initial appraisals of its launch is that it was to perform a valuable service to the scientific community. It would constitute a supplement to other journals and would be 
welcomed for its provision of translations of papers or memoirs informing British men of science of work about which they had no or little knowledge, thus reducing the likelihood of scientific efforts being duplicated or misguided. Taylor was so convinced of its usefulness that he was willing to produce it as long as he could defray his costs; his 'connexions' and 'profession' enabled him to produce Scientific Memoirs with less support 'than would be requisite if it were in other hands'. ${ }^{33}$ However, for the periodical to achieve that modest level of commercial success would require others to share Taylor's view of the importance of international exchange and translation for scientific progress.

Taylor's ideas found resonance among the eminent men of science; he boasted of statements of support from Ivory, Babbage, Powell, Forbes, Lloyd, Challis, Owen, Wheatstone, Phillips, Lubbock, Talbot, Hamilton and Faraday, and Hare, Henry and Bache in the US. ${ }^{34}$ The endeavour was publicly supported by publications like the Mechanics Magazine, as seen above, and the Literary Gazette. ${ }^{35}$ Importantly, the British Association for the Advancement of Science (BAAS) provided institutional backing which helped Taylor to persist with his project. On failing to cover the costs of producing Volume 1, Taylor appealed to BAAS for assistance at their $8^{\text {th }}$ annual meeting in 1838. The General Committee of the Association deemed it 'desirable to diffuse in this country the knowledge of the Scientific Memoirs published on the Continent' and placed $£ 100$ at the disposal of a newly formed committee with the remit of procuring and publishing foreign memoirs. ${ }^{36}$ Taylor was paid the first year's funding for the translation and publication of four memoirs by Gauss and three by Weber. The BAAS funding was renewed the following year and $£ 63$ was used to pay for the translation of a memoir by Ohm and for seven plates to accompany a paper by Gauss. The funding was also awarded in 1840 but only a small part of it was spent, on a plate for a paper by Weber. The balance was carried forward to 1841, and a portion of it was made available in 1842 too, but it remained unused, and no further funds were allocated. Some translations were also donated to Taylor via the BAAS committee (discussed below); these may have reduced his need for the available 
funding. In the preface to Volume 2 of Scientific Memoirs, Taylor acknowledged these forms of support. However, for Taylor the principal merit of the BAAS's involvement, was that it had 'afforded an opportunity for the plan and objects of the work to become more generally known', increasing sales. ${ }^{37}$ Thus, it appears that the BAAS helped to ensure the continuation of Scientific Memoirs primarily through promotion of the endeavour.

Concluding this discussion of Taylor's conception of translation, it is noted that, from Volume 2 onwards, Taylor reproduced a translated quotation from Goethe's Kunst und Alterthum on the verso of the title page of Scientific Memoirs, as follows:

Every translator ought to regard himself as a broker in the great intellectual traffic of the world, and to consider it his business to promote the barter of the produce of mind. For, whatever people may say of the inadequacy of translation, it is, and must ever be, one of the most important and meritorious occupations in the great commerce of the human race.

Goethe's image of the translator is described by Stark as 'barren and commercial', in contrast to more aesthetically pleasing or mystical metaphors of that period. ${ }^{38}$ However, it seems to have suited Taylor's scientific publishing context. Certainly it reflected his commercial concerns but also chimed, perhaps, with a self-perception both as knowledge broker and as a promoter of this form of brokerage.

\section{Gate-keeping}

Translation decisions may be studied at micro-linguistic levels of word choice, sentence structure, etc. and at macro-linguistic levels of information structure, textual organisation, etc. ${ }^{39}$ However, additional layers of decision making are also relevant, including the decision to translate and publish certain texts and authors, and not others. These decisions may be taken by authors, editors or translators but also patrons, publishers or other translation commissioners, and may be based on multifarious motivations. Taylor, as founder and editor of Scientific Memoirs, can be seen as both 
constructing and guarding the gate through which some foreign scientific works were allowed to pass. The responsibility for those editorial decisions was his but influence was also exerted by others on matters of content.

In an advertisement for Volume 1, Taylor provided a statement of his criteria for text selection; he hoped to identify the 'most interesting and important memoirs' on 'subjects of immediate interest', and to select research which was 'fully developed' and 'carefully recorded' and particularly to publish memoirs which were little known in Britain and had not appeared in English. ${ }^{40}$ However, he made it clear that he had no preconceived plan as regards choice or organisation of subjects but that he wanted the publication to address the pursuits of the men of science in Britain and to be 'illustrative of the objects of inquiry which most engage their attention' ${ }^{41}$ Through these and other editorial statements, Taylor invited eminent men of science to assist him in selecting and preparing memoirs, later using their involvement as a selling point for Scientific Memoirs. One illustration of how Taylor solicited recommendations is offered by his correspondence with William Fox Talbot. As noted by Crilly, Taylor and his co-editors of the Philosophical Magazine felt there was limited interest among their readers in pure mathematics; ${ }^{42}$ this perspective is reflected in Taylor's letter to Fox Talbot in which he sought advice on mathematics coverage for Scientific Memoirs, implying that he wished to cover just enough for the work to be useful but also sufficiently popular to sell. ${ }^{43}$ Fox Talbot replied by recommending the translation of work by Fresnel, Crelle and Gergonne. Among others known to have made recommendations or supplied material were Brooke (recommending Becquerel), Faraday (Mossotti and Plateau), Powell (von Wrede), Walker (Sefström), Main (Hansen), Brewster (Neumann), Herschel (Becquerel) and Thomas Richardson (Bunsen).

As noted above, Taylor received several translations, 'gratuitously presented', through the BAAS committee set up for this purpose, for publication in Volumes 2 and 3 of Scientific Memoirs. Sabine supplied translations (most likely produced by his wife Elizabeth) of texts by Gauss, Encke, Weber and two by Bessel for Volume 2. Two short papers by Rudberg donated by William H. Miller 
also appeared in this volume. Volume 3 contained three works by Gauss, two by Lamont and one by Dove which had been supplied via Sabine, one work each by Redtenbacher and de la Provostaye donated by Thomas Graham, and one by Gauss presented by Miller. William Jardine supplied Taylor with two translations, via the same committee, of texts by Bischoff and Müller, although these were never published in the Scientific Memoirs. It is noteworthy that Sabine, a key figure in the BAAS, who served on the committee for procuring translations, helped to ensure that his own field of interest, geomagnetism, was well represented in Scientific Memoirs through the works by Gauss, Weber and Lamont. $^{44}$

William Francis, Taylor's son who had studied chemistry in Germany, translated a number of texts from German for Scientific Memoirs, and other publications. ${ }^{45}$ However, Taylor also relied on Francis to provide recommendations for material to be translated and assessments of the value of German texts. For example, a list written by Francis comprising papers that had been 'sent by their respective authors' contained works by Lenz (including the one published in Volume 1) and others not published in Scientific Memoirs, with one annotated as 'short and interesting'. ${ }^{46}$ Two papers by Jacobi, one a sequel of the other, were also listed by Francis as material to be considered; these were both published in Volumes 1 and 2. Francis wrote of a recommendation from Poggendorff regarding a series of three papers by Riess comprising 'all that has lately been written in Germany respecting machine electricity'; a paper by Riess was published in Volume 4. The list also contained two papers by Ehrenberg under the heading 'zoological and geological' and one by Schleiden under the heading 'botanical'. One of Ehrenberg's titles was annotated as 'very long but exceedingly important' while Schleiden's memoir on phytogenesis was deemed 'important'. The latter appeared in Volume 2 of Scientific Memoirs while the former was split across parts in Volume 3.

These examples and others reflect a range of putative motivations for men of science to make recommendations to Taylor for inclusion or exclusion of specific material. Their arguments were primarily constructed around the reputation of the author, the originality and quality of the 
work and the accessibility, both physical and conceptual, of the original text to those conducting science in Britain. Francis's recommendations were particularly valuable to Taylor, since Francis was very familiar with current German research and could also supply translations of some of these works. Sabine's position also enabled him to exert some influence on contents, through his recourse to his wife's translations which he could offer to Taylor free of charge. In doing so, he, like others, sought to ensure that his own scientific interests were given due coverage in Scientific Memoirs.

It seems there was some prestige attached to having texts translated and published in Scientific Memoirs, particularly in later years. This led to authors asking for their work to be published there, or sending material to be considered for inclusion. In correspondence between Faraday and Plateau in 1849, for instance, Plateau explained that he had sent his memoir to Taylor asking for it to be translated and published in Scientific Memoirs, as his first memoir had already been included. Plateau now asked Faraday to support his request to Taylor. ${ }^{47}$ Six months later Plateau wrote again, this time noting that Wheatstone had agreed to do the translation but that he had heard nothing further; Plateau insisted on the great importance for him of getting this memoir published in Scientific Memoirs and again asked Faraday to intercede and obtain some information on progress. ${ }^{48}$ This may be regarded as indicative of the reputation and standing which Scientific Memoirs had gained by this time, and of the desire of men of science outside Britain to have their work disseminated in English in it. Other examples include Mossotti, who, having been published in Volume I (communicated by Faraday), submitted two more papers to Scientific Memoirs via Craufurd, who translated them for Volume 3. Similarly, Dove supplied a memoir for translation for Volume 4, having previously been published in Volumes 1 and 3.

Having availed himself of recommendations and offers to translate or revise translations, Taylor, through his prefaces, later highlighted what he considered to be the main intellectual achievements of Scientific Memoirs. It had presented 'the entire series of Melloni's important investigations' in English for the first time. It had published Becquerel's work on the artificial 
production of crystallised minerals by means of voltaic action, of relevance to Fox and Crosse's work recently communicated to the BAAS, but seemingly unknown to them and their auditors. ${ }^{49}$ Also worthy of mention was the publication of work by Gauss and Weber, in English for the first time, and of 'a highly valuable memoir' by Heinrich Rose and another by Melloni. ${ }^{50}$ Taylor summarised the contribution made by Volume 4 in terms of the subjects of inquiry of interest in Britain, namely heat and elasticity of gases and vapours (with contributions by Holtzmann, Magnus and Regnault) and the theory of light and colours (Wartmann, Neumann, Seebeck and Biot). ${ }^{51}$ Contributions of Volume 5 singled out for mention by Taylor were Plateau's research on the figure of equilibrium, Fresnel's 'celebrated treatise' on double refraction, Plücker's papers on diamagnetism, Weber's 'important memoir' on the measures of electro-dynamic forces and Knoblauch's much lauded investigations on radiant heat. ${ }^{52}$ These highlights were used by Taylor to attract subscriptions and sales but may also be read as his frank assessment of the most valuable scientific contributions of Scientific Memoirs. Viewed thus, they may form a useful starting point for future studies of reception which would aim to establish whether and how the translations of these works, in particular, might have informed subsequent research in Britain.

\section{Localisation}

Today, localisation designates the adapting of a software product or a website to a 'locale', a local/regional user group, and is an activity which involves translation, among other processes. ${ }^{53} \mathrm{In}$ analogous fashion, we can apply the concept to Taylor, who may be considered as having adapted the scientific ideas communicated in Scientific Memoirs for a local user group, namely those men of science reading Scientific Memoirs. An insight into potential readership is gained from lists of subscribers, published by Taylor as part of promotional material. In 1838, the list comprised 74 individual subscribers and 21 institutions, and Taylor acknowledged the support of the Royal Irish Academy (via Hamilton), in particular, in their permanent subscription for twenty copies. ${ }^{54}$ Among the individuals listed were many of those supporters named above, and institutions comprised 
colleges, universities and other libraries and institutions in England and Scotland and a handful of institutions in Ireland, the US and India. By the time Volume 2 had been concluded and Volume 3 was commenced, in 1841 , the number of individual subscribers had risen to 147 . The institutional list had grown to 35 and now also included numerous English regional philosophical, scientific and literary societies, through which more readers may have had the opportunity to access the publication. ${ }^{55}$

As editor, Taylor intervened overtly in some of the papers published in Scientific Memoirs through the addition of footnotes, signed 'ED'; these are present in approximately one quarter of the papers. The notes appear to have served the primary function of offering contextual information of presumed relevance to readers of the English translations. One obvious localising strategy can be seen in notes giving information about converting units of measurement or use of chemical symbols. Taylor's intervention can also be observed in some papers where an author's footnote makes reference to a work in a language other than English; in those instances Taylor added a note to inform readers of the existence of an English translation of that work, often in a previous part of Scientific Memoirs or in the Philosophical Magazine. Similarly, some of Taylor's notes consisted of additional references, not mentioned at all by the author. Here, Taylor drew connections with published work with which readers might already be familiar, thus framing their reading by encouraging them to consider the associations between the translated research and similar or contrasting ideas. These interventions may have served a secondary purpose of promoting other parts of Scientific Memoirs and other publications from Taylor's catalogue. For example, in the translation of a paper by Knoblauch in Part XVIII, the author's reference in a footnote to Ohm's law is supplemented by Taylor, in brackets, with a reference to Ohm's papers in Scientific Memoirs Parts VII and VIII. Subsequent editor's notes in the same paper inform us that Knoblauch's results agree with Powell's and the reader is invited to consult Powell's paper in Philosophical Transactions of $1825 .^{56}$ 
In some cases, Taylor's additions were more extensive and pointed towards more overt assessment of the contribution made by the papers. An example may be seen in the editor's note added to the translation of a paper by Plateau. Taylor informed the readers that Faraday had repeated many of Plateau's 'remarkable and beautiful' experiments but, in doing so, he coloured his oil green to make it more visible; Taylor's note explained how this was 'easily done', thus simultaneous encouraging readers to replicate the findings and conveying Faraday's enthusiasm for Plateau's contribution. ${ }^{57}$ Other examples can be seen in Volume 3 , which contains a celebrated paper by Menebrae on Babbage's 'Analytical Engine' and a set of three papers by Moser on latent heat. ${ }^{58}$ In both cases, Taylor gave more extensive editor's notes, including a set of references and some extracts of letters on and appraisals of the topics in question.

At times, Taylor's editorial position obliged him to engage with scientific controversy. For example, he used an editorial note to defend the inclusion of a translation of a work by Sefström as 'acceptable and useful' to inform further investigations, 'whatever opinion may be entertained with regard to the reasonings of $\mathrm{Mr}$ Sefström, and the hypothesis which he proposes' ${ }^{59} \mathrm{~A}$ more controversial case can be seen in the translation of Wartmann's work entitled Memoir sur le Daltonisme, which was published in Volume 4 (Part XIII) of Scientific Memoirs. ${ }^{60}$ In the early part of the article, Wartmann explained that the subject of his paper was those who are naturally incapable of distinguishing between a number of colours, applying the term 'Daltonism' to this condition. This term had been proposed by Prevost, and used as early as 1827, 'because the illustrious natural philosopher Dalton has described, as existing in his own case, many particulars of it'. Wartmann added a footnote to explain that he had not invented this nomenclature but was using it to avoid introducing a new one. He conceded that Whewell was right in asserting that 'few persons desire to be immortalized by their imperfections, and that Dalton, above all others, has no need of such a means of transmitting his name to posterity' but Wartmann did not favour Whewell's proposed alternative term for 'daltonian', which was 'idiopt' ${ }^{61}$ Brewster reviewed Wartmann's French memoir 
in Philosophical Magazine shortly before its English translation was published in Scientific Memoirs, and it seems that Brewster had seen Taylor's translation (perhaps revising it before publication). In his review Brewster objected strongly to the use of the term 'daltonian' and also responded robustly to Wartmann's criticisms of aspects of Brewster's own work in this area.

Taylor, in publishing an English translation of Wartmann's work in cognisance of the contested nomenclature and the other ongoing scientific disagreements between Wartmann and Brewster, was obliged to adopt a position but also explain it. He did so by annotating the translation with notes to alert readers to Brewster's criticisms and responses. For example, with regard to the controversial term itself, Taylor added a note immediately below Wartmann's, as follows:

Sir David Brewster, in his remarks on this memoir (Phil Mag for Aug. 1844, p. 134), expresses his regret that the author should have continued to employ this term, which he censures as degrading to the venerated name of Dalton, and faulty in regard of nomenclature. It is with reluctance that the Editor becomes accessary to the retention of this objectionable denomination, for which he would have much preferred to substitute Parachromatism, Parachromatic, \&c [...] but he is advised that such a change would be beyond the province of a translator. He has, however, ventured to add, in the title merely, the term Colour Blindness, adopted by Sir David Brewster [...].

The English title given by Taylor was 'On daltonism [dyschrosis, or colour blindness]'. By adding this note, Taylor duly acknowledged the controversy and made reference to the difficult position in which he found himself but his remarks and the decision taken also give a rare insight into Taylor's own 'theory' of translation. Although he did not wish to, Taylor felt obliged to retain Wartmann's term, since, in his view, a translator did not have the right or authority to substitute it, despite the availability of alternative or competing terms. However, to reflect the lack of support for Wartmann's position and to appease Brewster and other British readers, it was acceptable to 
intervene editorially to add those alternatives to the title, albeit in brackets, and to annotate with an account of the controversy and a clear statement of support for Brewster and against Wartmann.

\section{Editorial mode}

The evidence examined here indicates that Taylor believed in the usefulness of a periodical devoted to translations for disseminating foreign research in Britain, at a time when European science lacked a lingua franca. It seems that others shared this view. However, the difficulty experienced by Taylor in covering the costs of production belies the supposed level of support and prompts closer consideration of the material and socio-cultural contingencies of this translation and publishing activity. Brock and Meadows estimate that, at the time of publication of Volume 5, Taylor had spent at least $£ 1,800$ on Scientific Memoirs and had taken some $£ 1,500$, not recouping all costs until $1875 .^{62}$ The initial print run of 750 for Part I of Volume 1 was reduced to 500 for Parts II-IV and then increased to 525 for subsequent parts; these sold gradually as back issues rather than all at once on publication. ${ }^{63}$ This financial situation must also be evaluated against the knowledge that numerous translation and revising services were donated, i.e. supplied willingly but without remuneration, ${ }^{64}$ and that Taylor, as editor, publisher and printer, was, by his own admission, far better placed to support such a journal than most others would be.

As seen above, Taylor argued that postage costs constituted a major obstacle to commercial success and that few scientific journals managed to survive or sell more than 500 copies (and here Taylor discounted the 'entertaining miscellany' of the popular science magazines with much larger circulations). ${ }^{65}$ However, it may be argued that there were other flaws in execution which reduced the usefulness of the translation venture. Scientific Memoirs was priced at $6 \mathrm{~s}$ per part, and Hunt claimed some years later that it, among other journals, 'ought not to be expected to succeed at such prohibitory prices' ${ }^{66}$ There were increasingly long intervals between parts as the volumes progressed, causing Faraday to remark in a letter to Schönbein in 1852: 'It is a very great shame to 
us that such [German] papers do not appear at once in English but somehow we cannot manage it. Taylor appears to be much embarrassed in respect of the Scientific Memoirs' ${ }^{67}$ The hope for more regular publication and wider circulation was expressed by Taylor himself when he announced his resignation from the editorship of Scientific Memoirs in that year. ${ }^{68}$ While commercial success, or lack of it, might be gauged thus, it is clear that closer and more detailed assessment of intellectual, scientific contribution is also needed. Thus, one major avenue for further research, as noted above, is to focus specifically on the reception of Scientific Memoirs, developing and applying a methodology to assess the significance of specific translated texts to their readers and their impact on the development of scientific ideas and methods in Britain.

Consideration of Taylor's editorial mode may provide an alternative explanation for the fate of Scientific Memoirs. Philpotts' Bourdieu-inspired typology of editorship, developed in a study of literary journals, seems readily applicable to this case ${ }^{69}$ Bourdieu's notion of habitus, i.e. 'systems of durable, transposable dispositions ${ }^{70}$ accounts for agents' ability to act and respond to experiences in ways which are neither mechanistic nor consciously reasoned but which emanate from past experiences, from processes of socialisation and acculturation. Philpotts ascribes habitus to both editor and journal, and proposes two types of editorship, charismatic and bureaucratic, to characterise the interaction between the editor's personal habitus and the journal's institutional habitus.

There is significant symbolic capital associated with successfully pursuing a journal's intellectual agenda, acquiring contributions from leading, reputable authors and thereby commanding respect in the field. This is clearly the case for Scientific Memoirs; it acquires the public and material support of eminent men of science, largely through Taylor's social capital, i.e. through the networks of connections which he could personally mobilise. One of many illustrations of Taylor's networks is seen in his description of acting, daily, as a communication node for his authors, in defiance of the postal system, when he received private letters in parcels of proofs and passed 
those letters on to their final destinations in London. ${ }^{71}$ However, Taylor's social capital was not only acquired passively through his position as a London-based publisher. He also made efforts to expand that capital, for example, through his service to the learned societies. On the title page of Scientific Memoirs, for example, Taylor presents himself as a Fellow of the Linnæan, Geological, Astronomical, Asiatic, Statistical and Geographical Societies of London, an honorary member of the Natural History Society of Moscow and Under-Secretary of the Linnæan Society. As seen above, Taylor was personally committed to Scientific Memoirs and, insofar as the journal's purpose and ethos were defined, they embodied Taylor's vision and were determined by him alone. There are thus many parallels between Taylor and the literary editors described by Philpotts as exercising a charismatic mode of editorship, defined as 'a deeply personalized realization of the editorial role where the combined capital accumulated by the post-holder is validated largely in their own name and persona', ${ }^{72}$ The personalised nature of a charismatic editorship can result in the collapse of a journal when the editor burns out and the capital accumulated cannot be transferred easily to a new editor. ${ }^{73}$ As noted above, when Scientific Memoirs passed to other editors after Taylor's health failed, only one more volume was produced.

In the literary journals studied by Philpotts, charismatic editors tended to have little understanding of the financial circumstances of their journals, often unwittingly putting them in jeopardy in ways which were less likely to happen in the bureaucratic mode of editorship, i.e. 'where the capital associated with a journal rests not with the individual personality of the editor but in the institutional structures of the journal' ${ }^{74}$ This lack of commercial savvy does not apply Taylor, who was fully aware of the material, social and commercial conditions of publishing. However, we have seen above that he chose to subordinate the conventional, profit-making aspirations of a commercial publishing house to his personal vision for Scientific Memoirs.

Extending Bourdieu's understanding of the editor as someone of dual, opposing sets of dispositions ${ }^{75}$ - commercial and intellectual - Philpotts draws on Lahire to argue for a more 
pluralistic view of editorial dispositions. ${ }^{76}$ Considered in that manner, the ideal editor combines a range of competences and multiple dispositions. ${ }^{77}$ While Taylor principally exercised a charismatic mode of editorship in Scientific Memoirs, his editorial mode for other publications, e.g. the Philosophical Magazine, still published today, might well be characterised as more bureaucratic and more aligned with the institution and agency of the journal. ${ }^{78}$ Philpotts' third mode of editorship, 'mediating editorship', represents this convergence of those multiple dispositions, which are often in conflict. ${ }^{79}$ It is perhaps most useful to conceive of Taylor in that light; his multiple dispositions intellectual, scientific, commercial, institutional, social, personal - could be activated or suppressed in the different contexts of his extensive editorial practice. Philpotts argues that the predominantly charismatic mode of editorship is typical of little magazines, innovative but short-lived, while a more sustained and dominant presence of literary reviews is made possible through the more bureaucratic mode of editorship. It might then be hypothesised that Taylor's predominantly charismatic, personalised mode of editorship in Scientific Memoirs prevented a more bureaucratic, institutionalised mode from developing, as would be typical for a more established journal.

Finally, we must also take into account the unique nature of Scientific Memoirs, a journal of translations, which Taylor recognised as an experiment and which his succeeding editors also described thus. ${ }^{80}$ We may posit that, as a heterodox publication, and despite Taylor's drive, motivation and networks, it was not able to command sufficient symbolic capital in the fields of science and scientific publishing to enable it to compete with conventional periodicals or match them in longevity. A comparison of Scientific Memoirs with contemporaneous scientific journals and with journals of scientific translations produced in other contexts may serve to address this question, forming a second major area for further research, closely allied to the study of reception proposed above. $^{81}$ 


\section{Conclusion}

This case study provides a detailed account of a translating and publishing endeavour in mid-19th century British science, focused on Taylor's editorial role, through which he sought to exercise his gate-keeping and localising functions in the service of scientific advancement. In addition, it serves to show how scientific translations may be studied, not merely as instances of information transfer or exchange across linguistic borders, but also in relation to their social, material and scientific conditions of production. In doing so, the interests of translation scholarship and historical scientific scholarship appear to converge, providing a compelling case for collaborative research efforts which can coherently bring together linguistic, social, historical and scientific data, methods and expertise to reach a fuller understanding of translation as socio-historical practice.

\footnotetext{
${ }^{1}$ For a more detailed account than can be presented here, see Jeremy Munday, Introducing Translation Studies: Theories and Applications, London and New York: Routledge, 2001/2008 and Chapter 1 of Maria Tymoczko, Enlarging Translation, Empowering Translators, Manchester: St Jerome, 2007.
}

\footnotetext{
${ }^{2}$ See Martha P.Y. Cheung (ed.), An Anthology of Chinese Discourse on Translation, Manchester: St Jerome Publishing, 2006 and Part II of Mona Baker (ed.) Routledge Encyclopedia of Translation Studies, London and New York: Routledge, 1998/2008.
}

\footnotetext{
${ }^{3}$ Michaela Wolf, 'Sociology of Translation', in Yves Gambier and Luc Van Doorslaer (eds.), Handbook of Translation Studies, Amsterdam and Philadelphia: John Benjamins, 2010, pp. 337-43.
}

\footnotetext{
${ }^{4}$ See, for example, Moira Inghilleri (ed.), The Translator (2005) 11, no. 2; Michaela Wolf and Alexandra Fukari (eds.), Constructing a Sociology of Translation, Amsterdam and Philadelphia: John Benjamins, 2007; Hélène Buzelin, 'Unexpected allies: how Latour's Network Theory could complement Bourdieusian analyses in translation studies', The Translator (2005) 11, no. 2, pp. 193-218; Theo Hermans, The Conference of the
} Tongues, Manchester: St Jerome Publishing, 2007; Sergey Tyulenev, Applying Luhmann to Translation Studies: Translation in Society, London and New York: Routledge, 2012. 


\footnotetext{
${ }^{5}$ This argument is expanded on in Javier Franco Aixelá, 'The study of technical and scientific translation: an examination of its historical development', Journal of Specialised Translation (2004) 1, pp. 29-49, and in Maeve Olohan, 'Scientific and technical translation', in Francesca Bartrina and Carmen Millan Valera (eds.), Routledge Handbook of Translation Studies, London and New York: Routledge, 2012, pp. 441-454.

${ }^{6}$ These include works like Dimitri Gutas, Greek Thought, Arabic Culture: The Graeco-Arabic Translation Movement in Baghdad and Early Abbāsid Society (2nd-4th/8th-10th Centuries), London and New York: Routledge, 1998; Scott L. Montgomery, Science in Translation: Movements of Knowledge Through Cultures and Time, Chicago: University of Chicago Press, 2000, and selected papers in Maeve Olohan and Myriam SalamaCarr (eds.), The Translator (2011) 17, no. 2.
}

\footnotetext{
${ }^{7}$ See, for example, Maeve Olohan, 'Volunteer translation and altruism in the context of a nineteenth-century scientific journal', The Translator (2012) 18, no. 2, pp. 193-215.

${ }^{8}$ Matthew Philpotts, 'The role of the periodical editor: literary journals and editorial habitus', The Modern Language Review (2012) 107, no. 1, pp. 39-64.
}

${ }^{9}$ Taylor's life and work are discussed in detail in a chronicle of the publishing house, in a first and then expanded second edition, by William H. Brock and Arthur J. Meadows, The Lamp of Learning: Taylor \& Francis and the Development of Science Publishing, 1st ed. , London: Taylor \& Francis, 1984; William H. Brock and Arthur J. Meadows, The Lamp of Learning: Two Centuries of Publishing at Taylor \& Francis, 2nd ed. , London: Taylor \& Francis, 1998. Shorter accounts are offered by William H. Brock, 'The development of commercial science journals in Victorian Britain', in Arthur J. Meadows (ed.) Development of Science Publishing in Europe, Amsterdam: Elsevier, 1980, pp. 95-122, and William H. Brock, 'Taylor, Richard (1781-1858)', Oxford Dictionary of National Biography, Oxford: Oxford University Press, 2004. Taylor owned the company from 1804. A sevenyear period of partnership with his nephew resulted in the company name 'Richard \& John E. Taylor', which later changed to 'Taylor and Francis' when William Francis took over from 1852.

${ }^{10}$ Brock and Meadows (1998), op. cit. (9), pp. 103-5. 
${ }^{11}$ Richard Taylor (ed.), Scientific Memoirs, Selected from the Transactions of Foreign Academies of Science and Learned Societies, and from Foreign Journals, Vol. 1, London: Richard and John E. Taylor, 1837; Richard Taylor, (ed.), Scientific Memoirs, Vol. 2, London: Richard and John E. Taylor, 1841; Richard Taylor (ed.) Scientific Memoirs, Vol. 3, London: Richard and John E. Taylor, 1843; Richard Taylor (ed.), Scientific Memoir, Vol. 4, London: Richard and John E. Taylor, 1846; Richard Taylor (ed.) Scientific Memoirs, Vol. 5, London: Richard and John E. Taylor, 1852. These volumes are also available in a 1966 reprint by the Johnson Corporation, New York.

${ }^{12}$ Richard Taylor, 'Preface to the first volume', in Richard Taylor (ed.), Scientific Memoirs, Vol. 1, London: Richard and John E. Taylor, 1837.

${ }^{13}$ E. Lenz, 'On the laws of the conducting powers of wires of different lengths and diameters for electricity', in Richard Taylor (ed.), Scientific Memoirs, Vol. 1, London: Richard and John E. Taylor, 1837, p. 312.

14 'Taylor's Scientific Memoirs', Mechanics' Magazine, February 7, 1837, p. 350.

${ }^{15}$ Richard Taylor, 'Notice relative to the publication of the Scientific Memoirs', Philosophical Magazine (1837) 10 , no. 59 , p. 81

${ }^{16}$ Charles Babbage, Reflections on the Decline of Science in England, and on Some of Its Causes, London: B. Fellowes and J. Booth, 1830. Babbage's view was supported by, among others, David Brewster, 'Reflexions on the decline of science in England, and on some of its causes. By Charles Babbage, Esq., Lucasian Professor of Mathematics in the University of Cambridge, and member of several Academies', The Quarterly Review (1830) 43, no. LXXXVI, pp. 305-42.

${ }^{17}$ Richard Taylor, 'Advertisement to the first part', in Richard Taylor (ed.), Scientific Memoirs, Vol. 1, London: Richard and John E. Taylor, 1836.Taylor served, with Tilloch as co-editor and co-proprietor (as well as printer) of the Philosophical Magazine from 1822 to 1825 . After Tilloch's death, Taylor appointed Richard Phillips as coeditor in 1826, and David Brewster joined Taylor and Phillips in 1832 following an amalgamation of the Philosophical Magazine with his Edinburgh Journal, producing the London and Edinburgh Philosophical Magazine and Journal. 
${ }^{18}$ For their critique of Babbage's and Brewster's position, see 'Alleged decline of science in England', Mechanics' Magazine, May 26, 1832.

19 'Taylor's Scientific Memoirs', op. cit. (14).

20 'Taylor's Scientific Memoirs', op. cit. (14), p. 350.

21 'Taylor's Scientific Memoirs', op. cit. (14), p. 349.

${ }^{22}$ Taylor, 'Advertisement to the first part', op. cit. (17).

${ }^{23}$ Taylor, 'Preface to the first volume', op. cit. (12).

${ }^{24}$ First Report from the Select Committee of the House of Commons on Postage; together with the Minutes of Evidence and Appendix, in The Sessional Papers Printed by Order of The House of Lords, or Presented by Royal Command, in the Session 1837-38, vol. XXXIII, London, 1838, p. 315.

${ }^{25}$ First Report, op. cit. (24), p. 329.

${ }^{26}$ First Report, op. cit. (24), p. 324.

${ }^{27}$ First Report, op. cit. (24), p. 325.

${ }^{28}$ First Report, op. cit. (24).

${ }^{29}$ First Report, op. cit. (24).

${ }^{30}$ For discussion of the particular situation of commercial science journals and their publishers, see Brock, 1980, op. cit. (9).

31 'Taylor's Scientific Memoirs', Mechanics' Magazine, November 18, 1837, p. 112.

${ }^{32}$ Taylor, 'Preface to the first volume', op. cit. (12).

${ }^{33}$ Taylor, 'Notice relative to the publication of the Scientific Memoirs', op. cit. (15). See Olohan, op. cit. (7) for an application of economic concepts of pure and impure altruism to this case. 
${ }^{34}$ Taylor, 'Preface to the first volume', op. cit. (12). In a letter to Taylor, William Hamilton explained that he had used his inaugural presidential address to the Royal Irish Academy to call attention to the 'too great isolatedness which at present exists between the various learned bodies of the world' and he expressed hope that Scientific Memoirs would address this issue. William R. Hamilton to Richard Taylor, March 8, 1838, Taylor and Francis Archive, St Bride Library.

35 'The British Association. Ninth Meeting: Birmingham', Literary Gazette, London, September 7, 1839, pp. 5619, p. 569.

${ }^{36}$ Report of the Eighth Meeting of the British Association for the Advancement of Science, London: John Murray, 1839, p. xxv.

${ }^{37}$ Richard Taylor, 'Preface to the second volume', in Richard Taylor (ed.), Scientific Memoirs, Vol. 2, London: Richard and John E. Taylor, 1841.

${ }^{38}$ Susanne Stark, 'Behind Inverted Commas': Translation and Anglo-German Cultural Relations in the Nineteenth Century, Clevedon: Multilingual Matters, 1999, p. 13.

${ }^{39}$ Jiří Levý, 'Translation as a decision process', in Lawrence Venuti (ed.), The Translation Studies Reader, $1^{\text {st }}$ ed., London and New York: Routledge, 2000, pp. 148-59.

${ }^{40}$ Richard Taylor, 'Advertisement for Volume 1 of Scientific Memoirs', March 20, 1838, Taylor and Francis Archive, St Bride Library.

${ }^{41}$ Taylor, 'Advertisement to the first part', op. cit. (17).

${ }^{42}$ Tony Crilly, 'The Cambridge Mathematical Journal and its descendants: the linchpin of a research community in the early and mid-Victorian age', Historia Mathematica, 2004, 31, no. 4, pp. 455-497.

${ }^{43}$ Richard Taylor to William Henry Fox Talbot, May 3, 1836, The Correspondence of William Henry Fox Talbot, http://www.foxtalbot.arts.gla.ac.uk. 
44 'On the Translation of Foreign Scientific Memoirs', in Report of the Tenth Meeting of the British Association for the Advancement of Science, London: John Murray, 1841, pp. 446-7; Edward Sabine, 'On the Translation of Foreign Scientific Memoirs', in Report of the Eleventh Meeting of the British Association for the Advancement of Science, London: John Murray, 1842, p. 329; Edward Sabine, 'Report of the Committee for the Translation and Publication of Foreign Scientific Memoirs', in Report of the Twelfth Meeting of the British Association for the Advancement of Science, London: John Murray, 1843, p. 211.

${ }^{45}$ See Brock and Meadows, op. cit. (9), pp. 111-145.

${ }^{46}$ William Francis, 'Papers for Scientific Memoirs', n.d., Taylor and Francis Archive, St Bride Library.

47 Joseph Plateau to Michael Faraday, December 14, 1849, in Frank A.J.L. James (ed.), The Correspondence of Michael Faraday, London: Institution of Electrical Engineers, 1996.

${ }^{48}$ Joseph Plateau to Michael Faraday, July 8, 1850, in Frank A.J.L. James (ed.), The Correspondence of Michael Faraday, London: Institution of Electrical Engineers, 1996.

${ }^{49}$ Taylor, op. cit. (15), p. 83.

${ }^{50}$ David Brewster, Richard Taylor, and Richard Phillips, 'Scientific Memoirs, Part V', Philosophical Magazine (1839) 14 , no. 91, p. 473.

${ }^{51}$ Richard Taylor, 'Preface to the fourth volume', in Richard Taylor (ed.), Scientific Memoirs, Vol. 4, London: Richard and John E. Taylor, 1846.

${ }^{52}$ Richard Taylor, 'Preface to the fifth volume', in Richard Taylor (ed.), Scientific Memoirs, Vol. 5, London: Richard and John E. Taylor, 1852.

${ }^{53}$ Bert Esselink, A Practical Guide to Localization, Amsterdam and Philadelphia: John Benjamins, 2000.

${ }^{54}$ Taylor, 'Advertisement for Volume 1 of Scientific Memoirs', op. cit. (40). 
${ }^{55}$ Richard Taylor, 'Works published by Richard and John E. Taylor', in Richard Taylor (ed.), Scientific Memoirs, selected from the Transactions of Foreign Academies of Science and Learned Societies, and from Foreign Journals, vol. 3, London: Richard and John E. Taylor, 1841.

${ }^{56}$ H. Knoblauch, 'Investigations on radiant heat', in Richard Taylor (ed.), Scientific Memoirs, Vol. 5, London: Richard and John E. Taylor, 1852, pp. 188-237.

${ }^{57}$ J. Plateau, 'On the phænomena presented by a free liquid mass withdrawn from the action of gravity', in Richard Taylor (ed.), Scientific Memoirs, Vol. 4, London: Richard and John E. Taylor, 1846, pp. 16-43.

${ }^{58}$ Menabrae's paper is renowned for its translation by Ada Lovelace and her extensive translator's notes. The translator's notes are twice as long as the paper itself, and were prepared in collaboration with Babbage. Lovelace is credited with bringing substantial clarity and applicability to Babbage's work through these notes and their correspondence. For more details, see John Fuegi and Jo Francis, 'Lovelace \& Babbage and the creation of the 1843 "Notes", IEEE Annals of the History of Computing (2003) 25, no. 4, pp. 16-26.

${ }^{59}$ N.G. Sefström, 'Later observations, made partly in Sweden, partly in other countries, communicated in letters to the Royal Academy of Sciences', in Richard Taylor (ed.), Scientific Memoirs, Vol. 3, London: Richard and John E. Taylor, 1843, pp. 129-144.

${ }^{60}$ Elie Wartmann, 'On daltonism [dyschrosis, or colour blindness]', in Richard Taylor (ed.), Scientific Memoirs, Vol. 4, London: Richard and John E. Taylor, 1846, pp. 156-87.

${ }^{61}$ Wartmann, op. cit. (60), p. 158.

${ }^{62}$ Brock and Meadows, op. cit. (9), p. 105.

${ }^{63}$ Richard Taylor, 'Note on Disposal of Scientific Memoirs', July 20, 1841, Taylor and Francis Archive, St Bride Library.

${ }^{64}$ See Olohan, op. cit. (7).

${ }^{65}$ First Report, op. cit. (24), p. 322. 
${ }^{66}$ E. B. Hunt, 'Views and suggestions on the practice and theory of scientific publication', American Journal of Science and Arts (1858) XXVI, November, p. 29.

${ }^{67}$ Michael Faraday to Christian Friedrich Schönbein, 9 December 1852, in Frank A.J.L. James (ed.), The Correspondence of Michael Faraday, London: Institution of Electrical Engineers, 1996.

${ }^{68}$ Taylor, 'Preface to the fifth volume', op. cit (52).

${ }^{69}$ Philpotts, op. cit. (8).

${ }^{70}$ Pierre Bourdieu, Outline of a Theory of Practice, Cambridge University Press, 1977, p. 72.

${ }^{71}$ First Report, op. cit. (24).

${ }^{72}$ Philpotts, op. cit. (8), p. 48.

${ }^{73}$ Philpotts, op. cit. (8), p. 49.

${ }^{74}$ Philpotts, op. cit. (8), p. 53.

${ }^{75}$ Pierre Bourdieu, The Rules of Art: The Genesis and Structure of the Literary Field, trans. Susan Emanuel, Cambridge: Polity Press, 1996, p. 216.

${ }^{76}$ Bernard Lahire, 'From the habitus to an individual heritage of dispositions. Towards a sociology at the level of the individual', Poetics (2003) 31, no. 5-6, pp. 329-355.

${ }^{77}$ Philpotts, op. cit. (8), p. 54.

${ }^{78}$ Brock and Meadows devote a chapter to the history of the Philosophical Magazine, op. cit. (9), pp. 243-256.

${ }^{79}$ Philpotts, op. cit. (8), p. 61.

80 'Proofsheet for a Prospectus for New Series of The Scientific Memoirs', n.d., Taylor and Francis Archive, St Bride Library. 
${ }^{81}$ The Cambridge Mathematical Journal, contemporaneous with Scientific Memoirs, provides a useful point of comparison: Crilly, op. cit.(42). In the present-day, the Greek version of Scientific American, founded in October 2003 but succumbing to financial pressures and collapsing in April 2008, might be considered as an example of a periodical of scientific translation which struggled to acquire capital in its field: 'Mıкрn' Auтоßıүрафí [Short autobiography]', Scientific American - Greek Edition, n.d., http://www.sciam.gr/. 